\title{
Bioaccumulation and Consumption Safety of a Sea Food, Gastropod Mollusc (Thais coronata): Polycyclic Aromatic Hydrocarbon (PAH) Perspective
}

\author{
*11MOSLEN, M; ${ }^{1}$ ANIEKAN, I; ${ }^{1}$ ONWUTEAKA, J; ${ }^{2}$ MIEBAKA, CA \\ ${ }^{*}$ Department of Animal and Environmental Biology, Rivers State \\ University, Port Harcourt, Nigeria \\ ${ }^{2}$ Institute of Pollution Studies, Rivers State University, Port Harcourt, Nigeria. \\ *Corresponding Author Email address:moslen4c@yahoo.com; moslen.miebaka@ust.edu.ng
}

\begin{abstract}
Seafood and other environmental matrices are major entry route of harmful pollutants into humans due to constant contamination of the aquatic environment hence requires monitoring. This study scientifically explored the hypothesis that benthic gastropods bioaccumulate harmful pollutants that pose health risk to consumers of the sea food. Fifty samples of Thais coronata were collected per site from major regional fish landings. Two hundred samples were collected monthly for eight months to determine the concentrations of polycyclic aromatic hydrocarbon-PAH and possible health risks due to consumption using regulatory limits for guidance. Total PAH concentrations $(\mu \mathrm{g} / \mathrm{kg})$ varied between 65.68-173.52 suggesting differences in consumed concentrations at different times. The concentration of individual PAH congeners $(1.376 \pm 0.07-40.356 \pm 2.21 \mu \mathrm{g} / \mathrm{kg})$ and PAH4 were below the European Union maximum limits. The Daily Dietary Intake values ranged from $0.075-2.212 \mu \mathrm{g} / \mathrm{kg}$ for individual PAH congeners while that of PAH4 was $1.359 \mu \mathrm{g} / \mathrm{kg}$ and were all below their respective reference oral doses. The carcinogenic potencies of the PAH congeners ranged from 0.001-143.389, the carcinogenic toxic equivalents (TEQs) of all PAH congeners was 0.1522 while that of PAH4 was 0.0044. The Excess cancer risk (ECR) value $\left(10^{-8}-10^{-5}\right)$ was within USEPA guideline of $10^{-6}$ while the margin of exposure (MOE) of individual PAHs and PAH4 were higher than critical border line of 10,000 given by European Food Safety Authority but diagnostic ratio suggested PAH sources of pyrogenic origin in samples monitored. The study concluded low health risk for consumers of the shellfish (Thais coronata) in the study region but with recommendation advisory for regular monitoring to observe changes.
\end{abstract}

DOI: https://dx.doi.org/10.4314/jasem.v25i7.20

Copyright: Copyright $\odot 2021$ Moslen et al. This is an open access article distributed under the Creative Commons Attribution License (CCL), which permits unrestricted use, distribution, and reproduction in any medium, provided the original work is properly cited.

Dates: Received: 10 May 2021; Revised: 28 June 2021; Accepted: 01 July 2021

Keyword: Health-Risk; Bioaccumulation monitoring; Thais sp, Polycyclic Aromatic Hydrocarbon

The European Union had strongly recommended constant measurement of PAHs as wide as possible in food products in order to obtain data on the occurrence and specific concentrations in a variety of matrices (Wenz, et al., 2006). According to Bandowe et al., (2014) and Conte et al., (2016) polycyclic aromatic hydrocarbons (PAHs) are semi volatile organic compounds made up of two or more bonded aromatic rings in linear, angular or grouped pattern. The bioaccumulation of PAHs and its toxic effects with regards to marine organisms and onward transmission to humans via the food chain is a major health concern due to negative effects (Moslen et al., (2019). The origin of PAHs into the environment is both natural and anthropogenic. Major sources of PAH into the environment are mainly pyrogenic (including incomplete burning of coal, oil, gas, wood, garbage or other organic substances) and petrogenic inputs (Domingo and Nadal, 2015). PAHs are also classed as environmentally harmful pollutants (Nakata et al., 2014) and are widely detected in the aquatic environment, including water, sediment, fish, benthic invertebrates, sea birds, and sea mammals (Honda et al., 2018). Contaminated sediments constitute major source of pollution in estuaries and coastal delta systems because it becomes a sink for different organic and inorganic contaminants (Moslen and Ekweozor, 2016) which could further severely affect benthic community structure of the ecosystem (Daka and Moslen, 2013). Thais coronata is a species of sea snail. It is a marine benthic gastropod mollusc in the family Muricidae (the murex or rock snails) (WRMS, 2010). It is a shell fish of high economic and commercial value, consumed for its rich protein and vitamins content in southern Nigeria. In the aquatic ecosystem, benthic organisms are constantly exposed to environmentally harmful pollutants like PAHs particularly, in the Niger Delta region of Nigeria where oil and gas exploration and exploitation had led to the release of hydrocarbons into the aquatic environment. Indiscriminate feeding of fish and benthic organisms lead to bioaccumulation of 
pollutants in their tissues and gradual buildup of these pollutants in biota over time, could have harmful effect on humans who consume fish as their source of protein (Moslen et al., 2017). Thais coronata is one of such filter-feeding benthic gastropods capable of pollutant bioaccumulations and satisfies biomonitoring conditions like other aquatic gastropods. It therefore, becomes imperative to regularly monitor bioaccumulation of such harmful substances in marine benthic biota and further assess health risk hazard associated with consumption particularly, in areas where such data and information is lacking. This study therefore, seeks to fill the information gap in bioaccumulation of PAH and health risk concerns of consuming contaminated aquatic gastropod like Thais coronata.

\section{MATERIALS AND METHODS}

Collection of samples: Aquatic gastropod (Thais coronata) samples were freshly collected from regional fish landing ports (sites) located in southern Nigeria (Fig. 1). Samples were collected in two parts of fifty (50) per site (quadruplicate) irrespective of size and sex, making a total of 200 samples per month for the two landing ports. Sampling frequency was on a monthly basis for eight months (October 2018 - May 2019). Incremental sampling was done to ensure aggregate samples representative of lots or sub-lots for laboratory analysis (FSAI, 2015). The samples were wrapped in well labelled aluminum foils preserved in ice-chests and transported to the laboratory for analysis.

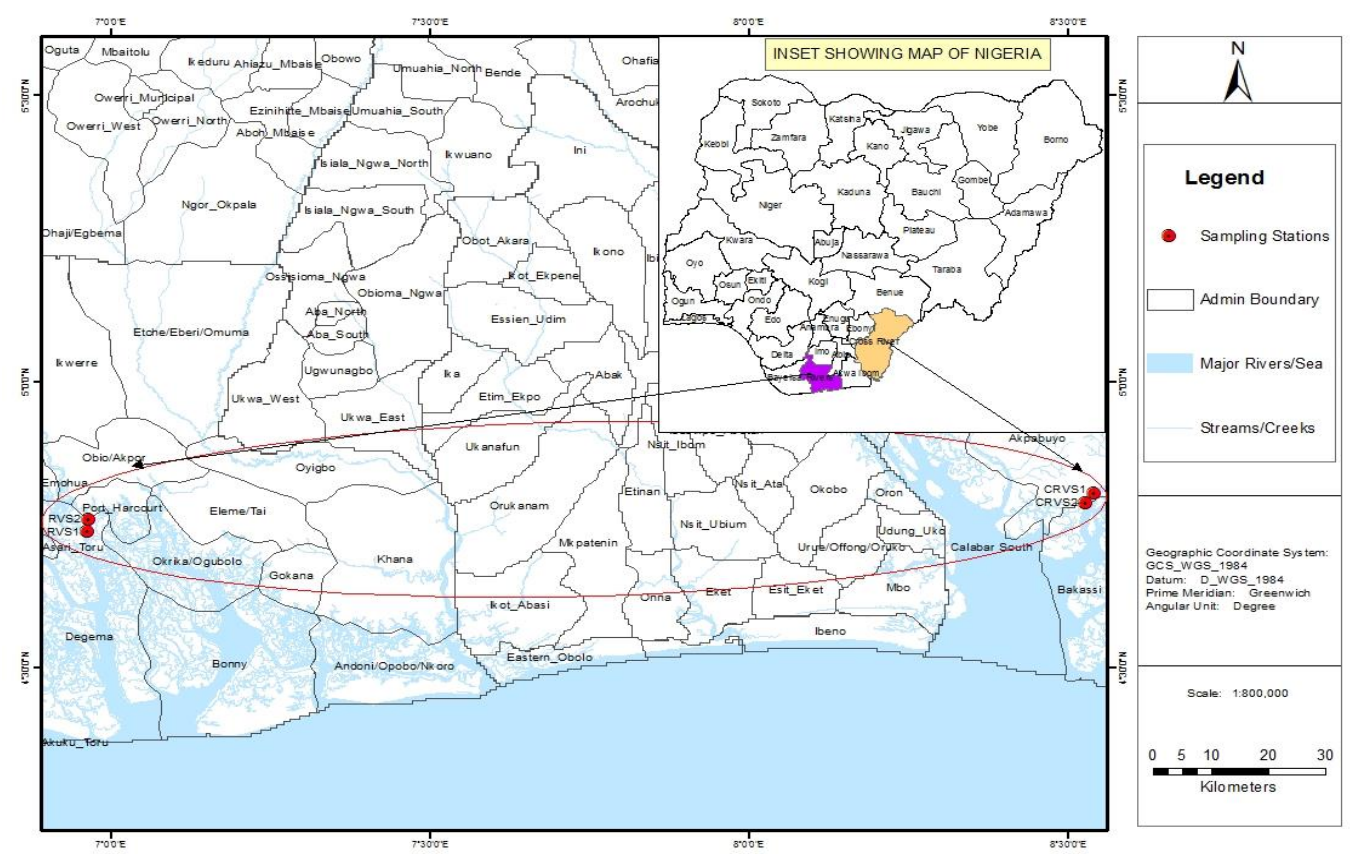

Fig. 1: Inset map (Nigeria) showing study area/region

Extraction and analysis: The extraction of PAH was achieved by the methods of (Pena et al., 2006). Gastropod samples (Thais coronata) were properly homogenized after extraction and oven drying. Anhydrous $\mathrm{Na}_{2} \mathrm{SO}_{4}$ was carefully mixed with $10 \mathrm{~g}$ of sample. Twenty (20) $\mathrm{ml}$ of dichloromethane was then added to the sample, covered with aluminum foil to avoid evaporation. Supernatant was then separated from extracts by sonication and concentrated using an evaporator. The extract was cleaned using a chromatographic column packed with $1 \mathrm{~cm}$ glass wool at the base. It was pre-eluted with twenty (20) ml dichloromethane after adding two (2) gram silica gel with $1 \mathrm{~cm} \mathrm{Na} \mathrm{NO}_{4}$ (anhydrous). Extracts were put in three (3) ml vials before gas chromatographic analysis.
Gas chromatographic (GC) analysis: Gas Chromatographic analysis was done with GC model: HP5890 Series II GC-FID for the PAH congeners as described (Tongo et al., 2017). The initial temperature of the $\mathrm{GC}$ was put at $60^{\circ} \mathrm{C}$ for two minutes and inclined at $25^{\circ} \mathrm{C}$ per minute and then increased to $300^{\circ} \mathrm{C}$ for five minutes before letting it to stay for fifteen minutes. The injection port temperature was placed at $250^{\circ} \mathrm{C}$ with a microlitre splitless injection mode, while the injection port of the flame ionization detector (FID) was kept at $300^{\circ} \mathrm{C}$. Fifteen important PAHs (Naphthalene -NaP, Acenaphthylene -AcPY, Acenaphthene-AcP, Fluorine-Flu, Phenanthrene-Phe, Anthracene-Ant, Fluoranthene -FL, Pyrene-Pyr, 
Benzo [a] anthracene-BaA, Chrysene-Chr, Benzo [b] fluoranthene-BbFL, Benzo [k] fluoranthene-BkFL, Benzo [a] pyrene-BaP, Indeno [1, 2, 3-cd] pyrene-Ind, Dibenzo [a, h] anthracene-DBA and Benzo [g, h, i] perylene-BP) were noted for the analysis. Comparison of the holding time of standards were done with that of extracts with individual examination of PAHs used for identification and quantization of different components recorded. The non-carcinogenic congeners assessed were Nap, AcPY, AcP, Flu, Phe, Ant, FL, Pyr while the carcinogenic ones were BaA, Chr, BkFL, BaP, BbFL, Ind, DBA and BP (USEPA, 1993). The limit of detection (LOD) was $0.0001 \mu \mathrm{gkg}^{-1}$. Recovery method involved use of surrogate standard and recovery rate was done by spiking of sample with known concentration of the surrogate. The concentration of the surrogate and the other samples was given by injection into the GC (Inengite et al., 2010). Analytical standards and reference used comply with those of (Wickliffe et al., 2018; Inengite et al., 2010).

Exposure assessment: Evaluation of the Dietary Daily Intake (DDI) by consuming PAHs contaminated seafood (Thais coronata) was done for adult population using equation. 1 (Halek et al., 2007). The average adult weight in Nigeria was taken as $70 \mathrm{~kg}$ (Tongo et al., 2017) obtained from data of the Food and Agriculture Organization (FAO, 2014) on fishery and aquaculture statistics (Tongo et al., 2018).

The Dietary Daily Intake (DDI)- ng/day) $=\mathrm{Ci} \times$ IFR eqn 1

Where $\mathrm{Ci}=$ concentration of $\mathrm{PAH}$ in bivalve samples and IFR=fish ingestion rate (IFR) (EFSA, 2005)

Health Risk Assessment: The following indices were used for health risk assessment due to exposure by consuming PAH contaminated sea food (Thais coronata). Evaluation of individual PAH carcinogenic potencies, carcinogenic toxic equivalents (TEQs), PAH4 (sum of BaA, Chr, BbFL, and BaP). The excess cancer risk (ECR) and Margin of exposure (MOE) were also assessed and compared with regulatory limits where applicable.

Carcinogenic potencies of individual PAHs $(\mathrm{B}(\mathrm{A}) \mathrm{Pteq})=\mathrm{Ci} \times \mathrm{TEFi}($ Tongo et al., 2018) - eqn 2

$\mathrm{TEFi}=$ toxicity equivalency factor as used by Nisbet and LaGoy, (1992)

Carcinogenic toxic equivalents (TEQs) $=\Sigma \mathrm{B}(\mathrm{A})$ Pteq (Szewczynska et al., 2013)
To calculate PAH4, it is the summation of $\mathrm{BaA}, \mathrm{Chr}$, $\mathrm{BbFl}$ and $\mathrm{BaP}$ ((FSAI, 2015) as used in equation 3.

PAH4 Index $(\mathrm{PAH} 4)=\sum B a A+B b F L+C h r+B a P$ - eqn (3)

The excess cancer risk was evaluated using equation 4 (Xia et al., 2010).

Excess Cancer Risk $(\mathrm{ECR})=\frac{\sum Q X B(A) P T e q X I F R X E D}{B W X A T n}$ eqn (4)

Where Carcinogenic potency of BaP (Q) $\mathrm{mg} \mathrm{kg}^{-1} \mathrm{~d}^{-1}$ (7.3) (Ding, 2012)

Exposure Duration $(\mathrm{ED})=30$ years $(\mathrm{Qu}$ et al., 2015)

Adult body weight $(\mathrm{BW})=70 \mathrm{~kg}$ (Tongo et al., 2105)

Average life span $(\mathrm{ATn})=8760$ days (Huang et al., 2014)

Evaluation of Margin of Exposure (MOE): MOE was also evaluated as an acceptable method of risk assessment approved by the Joint FAO/WHO Expert Committee on Food Additives (JECFA) and the European Food Safety Authority (EFSA 2005; FAO/WHO, 2005) as used in equation 5

$\mathrm{MOE}=\mathrm{BMD} 10 \times \mathrm{BW} / \mathrm{E}-$ eqn (5)

Where $\mathrm{BMDL} 10=70 \mu \mathrm{g} / \mathrm{kg}$ bw/day (for $\mathrm{BaP}$ ) or 340 $\mu \mathrm{g} / \mathrm{kg} \mathrm{bw} /$ day (for PAH4) (EFSA, 2008).

$\mathrm{E}=\mathrm{DDI}=$ Dietary Daily Intake (DDI) (Tongo et al., 2018)

BW=Adult body weight (BW) - $70 \mathrm{~kg}$ (Tongo et al., 2015)

Evaluation of PAH sources: The Ant/Ant+Phen, Flu/Flu+Py (Brandi et al., 2007), BaA/(BaA+Chry) (Nyarko et al., 2011) and LMW/HMW (Nasher et al., 2013) ratios were used for evaluation of possible sources of PAH in gastropod samples.

\section{RESULT AND DISCUSSION}

Concentration of $\mathrm{PAH}$ in Gastropod Samples Examined: The concentration of total PAH for each month was assessed and presented in Fig. 2. Total PAH concentrations $(\mu \mathrm{g} / \mathrm{kg})$ varied across the study period with values ranging from 65.68 - 173.52 suggesting that consumers of the gastropod (Thais coronata) were exposed to varying degrees of PAH at different times. The high molecular weight $\mathrm{PAH}$ 
congeners were generally dominant relative the low molecular weight components. The value of the current study was generally higher than those reported for marine bivalves (3.26 to $64.45 \mathrm{ng} / \mathrm{g}$ ) and

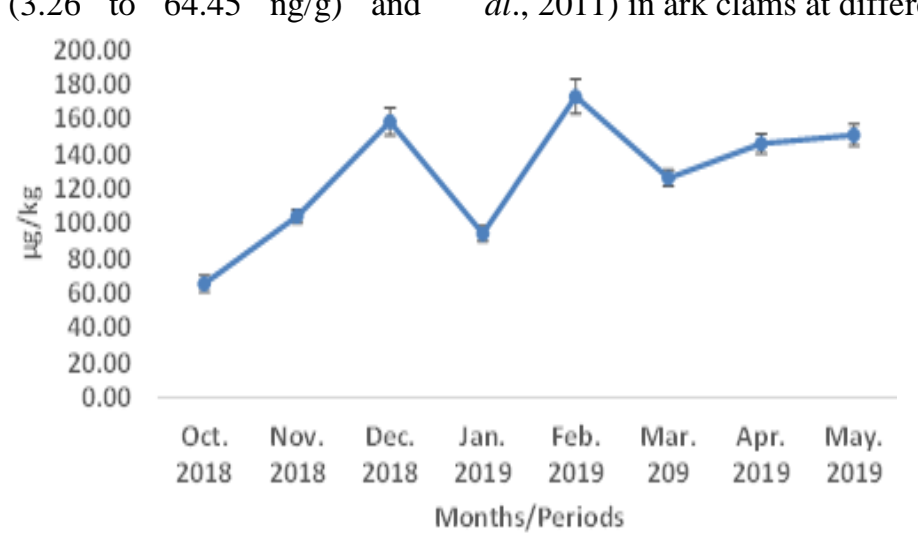

Fig.2: Temporal variation of total PAH concentrations for the study period gastropods (4.81 to $23.8 \mathrm{ng} / \mathrm{g}$ ) (Pham et al., 2019) but lower than total PAH concentrations $(634.7,476.7$, 129.5, 452.5 and $415.0 \mathrm{ng} \mathrm{g}^{-1}$ ) reported (Safahieh et al., 2011) in ark clams at different sites.
Individual PAH congeners also showed variations during the study period with concentrations $(\mu \mathrm{g} / \mathrm{kg})$ ranging from $1.376 \pm 0.07-40.356 \pm 2.21$ (Table 1 ) Indeno (1, 2, 3-cd) pyrene (Ind) had the highest mean concentration followed by Dibenzo $(a, h)$ anthracene (DBA) while Phenanthrene (Phe) had the lowest concentration. This corroborates the report of (Nwaichi and Ntorgbo, 2016) who also reported Ind as having the highest mean concentration (171.000 \pm $0.430 \mathrm{~g} \mathrm{~kg}^{-1}$ ) during their evaluation of shell fish obtained from the Niger delta region. The mean concentration of BbFL of this study was lower than the
European Union (EU) limit of $12.000 \mu \mathrm{g} \mathrm{kg}^{-1}$ while that of Ind exceeded the EU limit of $30.0 \mu \mathrm{g} \mathrm{kg}^{-1}$. Analysis of variance (ANOVA) (Table 2) indicated that variations observed were significantly different for the following PAH congeners between the study periods: Anthracene $\quad(\mathrm{p}<0.05)$ : Dec $<$ Apr $=$ May $=$ Feb $=$ Mar $<$ Jan $=$ Nov $=$ Oct; Benzo (a) anthracene $\quad(\mathrm{p}<0.01)$ : Oct $<$ Nov $=$ May $<$ Dec $=$ Mar $=$ Apr $=$ Jan=Feb; Benzo $(\mathrm{k})$ fluoranthene $\quad(\mathrm{p}<0.05)$ : $\quad$ Nov $<$ Feb $=$ Oct $=$ Dec $=$ May $<$ Mar=Apr=Jan; Dibenzo (a, h) anthracene $(\mathrm{p}<0.05)$ : Dec $<$ May $=$ Apr $=$ Mar $=$ Feb $=$ Nov $<$ Jan=Oct.

Table 1: Summary of Parameters (Mean Concentration, DDI, B (A)Pteq, ECR and MOE, TEQ, Ant/Ant+Phen, Flu/Flu+Py, $\mathrm{BaA} /(\mathrm{BaA}+\mathrm{Chry}$ and $\mathrm{LMW} / \mathrm{HMW})$ analysed during the study

\begin{tabular}{|c|c|c|c|c|c|c|}
\hline PAH Congeners & MEAN $\pm \mathrm{SE}$ & TEFs & $\begin{array}{l}\text { DDI } \\
\text { (CixIFR) }\end{array}$ & B(A)Pteq (Ci x TEFi) & ECR & MOE \\
\hline Naphthalene & $3.165 \pm 0.17$ & 0.001 & 0.173 & 0.003 & $6.19 \times 10^{-8}$ & $2.82 \times 10^{-7}$ \\
\hline Acenaphthylene & $4.032 \pm 0.22$ & 0.001 & 0.221 & 0.004 & $7.89 \times 10^{-8}$ & $2.21 \times 10^{-7}$ \\
\hline Acenaphthene & $2.992 \pm 0.16$ & 0.001 & 0.164 & 0.003 & $5.86 \times 10^{-8}$ & $2.98 \times 10^{-7}$ \\
\hline Fluorene & $2.278 \pm 0.12$ & 0.001 & 0.125 & 0.002 & $4.46 \times 10^{-8}$ & $3.92 \times 10^{-7}$ \\
\hline Phenanthrene & $1.376 \pm 0.07$ & 0.001 & 0.075 & 0.001 & $2.69 \times 10^{-8}$ & $6.49 \times 10^{-7}$ \\
\hline Anthracene & $3.739 \pm 0.20$ & 0.01 & 0.205 & 0.037 & $7.32 \times 10^{-7}$ & $2.39 \times 10^{-7}$ \\
\hline Fluoranthene & $5.065 \pm 0.27$ & 0.001 & 0.278 & 0.005 & $9.91 \times 10^{-8}$ & $1.76 \times 10^{-7}$ \\
\hline Pyrene & $5.343 \pm 0.29$ & 0.001 & 0.293 & 0.005 & $1.05 \times 10^{-7}$ & $1.67 \times 10^{-7}$ \\
\hline Benzo (a) anthracene & $13.811 \pm 0.75$ & 0.1 & 0.757 & 1.381 & $2.70 \times 10^{-5}$ & $6.47 \times 10^{-6}$ \\
\hline Chrysene & $2.031 \pm 0.11$ & 0.01 & 0.111 & 0.020 & $3.98 \times 10^{-7}$ & $4.40 \times 10^{-7}$ \\
\hline Benzo (b) fluoranthene & $2.445 \pm 0.13$ & 1 & 0.134 & 2.445 & $4.79 \times 10^{-5}$ & $3.65 \times 10^{-7}$ \\
\hline Benzo (k) fluoranthene & $2.594 \pm 0.13$ & 0.1 & 0.142 & 0.259 & $5.08 \times 10^{-6}$ & $3.44 \times 19^{-7}$ \\
\hline Benzo (a) pyrene & $6.516 \pm 0.35$ & 0.1 & 0.357 & 0.652 & $1.28 \times 10^{-5}$ & $1.37 \times 10^{-7}$ \\
\hline Indeno $(1,2,3$-cd $)$ pyrene & $40.356 \pm 2.21$ & 0.1 & 2.212 & 4.036 & $7.90 \times 10^{-5}$ & $2.21 \times 10^{-6}$ \\
\hline Dibenzo $(\mathrm{a}, \mathrm{h})$ anthracene & $28.677 \pm 1.57$ & 5 & 1.572 & 143.389 & $2.81 \times 10^{-5}$ & $3.11 \times 10^{-6}$ \\
\hline PAH4 & $24.804 \pm 1.35$ & & 1.359 & 152.244 & & $1.75 \times 10^{-7}$ \\
\hline TEQ & 0.1522 & & & & & \\
\hline \multicolumn{7}{|l|}{ Congeners) } \\
\hline TEQ (PAH4) & 0.0044 & & & & & \\
\hline Ant/Ant+Phen & 1.0013 & & & & & \\
\hline $\mathrm{Flu} / \mathrm{Flu}+\mathrm{Py}$ & 1.0053 & & & & & \\
\hline $\mathrm{BaA} /(\mathrm{BaA}+\mathrm{Chry})$ & 1.0020 & & & & & \\
\hline LMW/HMW & 0.1645 & & & & & \\
\hline
\end{tabular}


Table 2: summary of ANOVA output with adjusted Ms and Fvalues

\begin{tabular}{|c|c|c|}
\hline PAH Congeners & Adj MS values & F-values \\
\hline Naphthalene $^{\text {ns }}$ & 0.0000630 & 1.02 \\
\hline Acenaphthylene $^{\text {ns }}$ & 0.0000335 & 0.83 \\
\hline Acenaphthene $^{\text {ns }}$ & 0.0000465 & 2.02 \\
\hline Fluorene $^{\mathrm{ns}}$ & 0.0000151 & 1.50 \\
\hline Phenanthrene $^{\text {ns }}$ & 0.0000085 & 1.53 \\
\hline Anthracene* & 0.0000858 & 2.97 \\
\hline Fluoranthene $^{\text {ns }}$ & 0.0000831 & 1.65 \\
\hline Pyrene ${ }^{\mathrm{ns}}$ & 0.0001095 & 1.71 \\
\hline Benzo (a) anthracene** & 0.0018633 & 4.06 \\
\hline Chrysene & 0.0000058 & 0.82 \\
\hline Benzo (b) fluoranthene* & 0.0000144 & 2.43 \\
\hline Benzo (k) fluoranthene* & 0.0000211 & 2.65 \\
\hline Benzo (a) pyrenen ${ }^{\text {ns }}$ & 0.0000407 & 2.11 \\
\hline Indeno $(1,2,3$-cd $)$ pyrene $^{\text {ns }}$ & 0.002290 & 1.87 \\
\hline Dibenzo $(\mathrm{a}, \mathrm{h})$ anthracene* & 0.0027517 & 2.81 \\
\hline
\end{tabular}

Other parameters evaluated (Table 1) during the study included daily dietary intake $(D D I)$, potential toxic equivalence $(B(A)$ Pteq) of individual and total PAH congeners, Excessive cancer risk (ECR), Margin of exposure (MOE), mean concentrations and toxic equivalence (TEQ (PAH4) of PAH4 and different source ratios (Ant/Ant+Phen; Flu/Flu+Py; BaA/(BaA+Chry) and LMW/HMW).

The concentration of PAH congeners of the present study was lower than values (1.2 - 2.1 PPB) earlier reported (Wickliffe et al., 2018) but in consonance with concentrations $(9.49-31.23 \mathrm{ng} / \mathrm{g})$ reported by Barlow and Muralidharan, (2012). BaP had been reported as indicator or biomarker for the presence and effect of carcinogenic PAHs in foods by European Union commission (EC, 2006).

Mean concentration $(6.516 \pm 0.35 \mu \mathrm{g} \mathrm{kg}-1)$ of $\mathrm{BaP}$ in this study is below European commission maximum limit of $10 \mathrm{ng} / \mathrm{g}$ for PAH congeners in bivalves (fresh weight). Mean $\mathrm{BaP}$ value of this study also show variance with that $\left(79.0 \pm 30 \mathrm{ng} \mathrm{kg}^{-1}\right)$ reported by Moslen et al., (2019) in a similar study. BaP was concluded to be a human carcinogen with genotoxic effects by the International Agency for Research into Cancer (IARC) in 2012 (FSAI, 2015). European Food Safety Authority (EFSA) however, concluded that only $\mathrm{BaP}$ cannot be used to indicate $\mathrm{PAH}$ presence in food and recommended the use of PAH4 (the sum of $\mathrm{BaP}, \mathrm{BaA}, \mathrm{BbFL}$ and $\mathrm{Chr}$ ) (FSAI, 2015). The concentration of PAH4 of the current study was below the EU maximum limit of $30 \mu \mathrm{g} \mathrm{kg}^{-1}$ for PAH4 in the Commission Regulation (EU) No 835/2011 suggesting low health risk.

The presence of PAH compounds in foods will remain a source of concern due to carcinogenic and mutagenic effects. Consumption of contaminated foods is one certain route of exposure hence the assessment of daily dietary intake (DDI) in this study. The DDI values of the present study ranged from $0.075-2.212 \mu \mathrm{g} / \mathrm{kg}$ for individual PAH congeners while that of PAH4 was
$1.359 \mu \mathrm{g} / \mathrm{kg}$. The DDI values of the present study falls below the maximum $(0.0173 \mathrm{mg} /$ day $)$ reported by Tongo et al., (2017) for smoked fish in the Niger Delta region, apparently due to the higher consumption rate of smoked fish. However, the DDI values of the present study was within the range $(0 \quad-$ $0.0005 \mathrm{mg} / \mathrm{kg} / \mathrm{day}$ ) recorded by Tongo et al., (2018) for various shell fish in the study area but lower than the values $(0.10-2.33 \mathrm{mg} / \mathrm{kg}$ body weight/day $)$ observed by Olayinka et al., (2019) in fish and other shell fishes. It is pertinent to state that the DDI values of the present study were generally below the available reference dose (USEPA, 1993) of PAH congeners, implying minimal risk of exposure even at long-term consumption of the gastropod (Thais coronata) under investigation. The carcinogenic potencies $(\mathrm{B}(\mathrm{A}) \mathrm{Pteq})$ of the PAH congeners were also assessed and values obtained ranged from $0.001-143.389$ for Phenanthrene and Dibenzo (a, h) anthracene respectively while PAH4 had a value of 152.244 . The $\mathrm{B}(\mathrm{A})$ Pteq values obtained in this study is comparable to values ( 0.012 to $900.0 \mathrm{ng} \mathrm{kg}^{-1}$ ) reported by Moslen et al., (2019) in similar study except BaA, BbFL, Ind, and DBA with elevated values. The carcinogenic toxic equivalents (TEQs) of all PAH congeners was 0.1522 while that of PAH4 was 0.0044 in the present study.

The Excess cancer risk (ECR): Dietary exposure by consuming contaminated seafood could also predispose humans to Excess cancer risk (ECR) Moslen et al., (2019). Evaluation of ECR in this study showed values ranging from $10^{-8}-10^{-5}$. The observed ECR values of this study compared favourably with the acceptable guideline value of $10^{-6}$ (USEPA, 2001). This guideline limit implies cancer risk level of one in a million $\left(E C R=10^{-6}\right)$ during a seventy-year period of lifetime, is considered tolerable but a case of an extra lifetime cancer risk of one in ten thousand or greater $\left(\mathrm{ECR}=10^{-4}\right)$ is considered serious (Jing et al., 2013). This is however, also subject to some national and regional standards and legislations. ECR values of this study accords with those earlier reported Tongo et al., (2017) in similar studies

The margin of exposure (MOE) is defined as the ratio of the no-observed-adverse-effect level (NOAEL) or benchmark dose lower confidence limit (BMDL) for the critical effect to the theoretical, predicted or estimated exposure dose or concentration (WHO/IPCS, (2009). It is one of the most credible and practical scientific approach for the formulation of advice since it considers both the dietary exposure and the available data on the dose-response relationship when evaluating genotoxic and carcinogenic substances (Barlow et al., 2006). The extent of the MOE gives an indication of the level of concern, but 
not a precise quantification of the risk (Benford et al., 2010). The MOE of individual PAH congeners of this study ranged from $1.37 \times 10^{-7}-6.47 \times 10^{-6}$ while that of PAH 4 was $1.75 \times 10^{-7}$. The MOEs of individual PAHs and PAH4 were higher the critical border line of 10,000 given by EFSA, (2005) signifying low health risk exposure margin for consumers of the gastropod (Thais coronata) in the study area. The MOEs of this study were generally lower than figures earlier reported in similar studies (Wu et al., 2016). PAH source could be petrogenic or pyrogenic in origin. Certain diagnostic ratios could be used to differentiate the sources of PAHs with respect to their stability, physical and chemical attributes (Nasher, 2013). The Ant/Ant+Phen, Flu/Flu+Py, $\mathrm{BaA} /(\mathrm{BaA}+\mathrm{Chry})$ and $\mathrm{LMW} / \mathrm{HMW}$ ratios were applied in this study and the following values (1.0013, $1.0053,1.0020$ and 0.1645 ) obtained respectively. In the current study, the Ant/Ant+Phen ratio was $>0.1$ (Brandli et al., 2007); Flu/Flu+Py ratio was > 0.4 (Brandli et al., 2007), $\mathrm{BaA} /(\mathrm{BaA}+\mathrm{Chry})$ ratio was > 0.350 (Nyarko et al., 2011) and LMW/HMW ratio was <1 Nasher et al., (2013) suggesting PAH sources of pyrogenic origin in the gastropod samples studied. The $\mathrm{BaA} /(\mathrm{BaA}+\mathrm{Chry})$ values obtained in this study corresponds to values earlier reported in similar studies (Nwaichi and Ntorgbo, 2016; Nyarko et al., 2011) who also attributed PAH source of their samples to be pyrogenic in origin. Moslen et al., (2019) had linked major anthropogenic activities in the study area to petrogenic and pyrogenic sources including illegal petroleum refining/bunkering activities, burning of confiscated petroleum products on water ways and mangrove environments by security agencies, combustion of tyres/plastics and other organic substances of non-point sources within the Niger Delta region.

Conclusion: Regulatory agencies had recommended regular monitoring to detect PAHs in food due to carcinogenic and genotoxic health concerns posed by such chemicals. This study investigated a commonly consumed commercial seafood (Thais coronata) with respect to PAH contamination and health risk. Contamination concentrations in addition to standard health risk indices such as carcinogenic potencies, carcinogenic toxic equivalents, excess cancer risks and margin of exposure were evaluated and compared to available regulatory limits of USEPA and European Union. Concentration of PAH congeners were generally low except for Ind while health risk indices also compared lower than regulatory limits. Standard diagnostic ratios applied also suggested $\mathrm{PAH}$ of pyrogenic origin. The study therefore concluded low health risk concern for consumers of seafood (Thais coronata) in the study region but recommended constant monitoring to observe concentration changes.

\section{REFERENCES}

Bandowe, BAM; Bigalke, M; Boamah, L; Nyarko, E; Saalia, FK; Wilcke, W (2014). Polycyclic aromatic compounds (PAHs and oxygenated PAHs) and trace metals in fish species from Ghana (West Africa): bioaccumulation and health risk assessment. Environ. Inter. (65): 135-146.

Barlow, S; Renwick, AG; Kleiner, J; Bridges, JW; Busk, L; Dybing, E; Edler, L; Eisenbrand, G; Fink-Gremmels, J; Knaap, A; Kroes, R; Liem, D; Müller, DJG; Page, S; Rolland, V; Schlatter, J; Tritscher, A; Tueting, W; Würtzen, G (2006). Risk assessment of substances that are both genotoxic and carcinogenic Report of an International Conference organized by EFSA and WHO with support of ILSI Europe. Food and Chem. Toxicol. (44): 1636-1650.

Barlow, V; Muralidharan, S (2012). Polycyclic aromatic hydrocarbons in various species of fishes from Mumbai harbor, India and their dietary intake concentration to Human. Int. J. Oceanogr. doi:10.1155/2012/645178.

Benford, D; Bolger, PM; Carthew, P; Coulet, M; DiNovi, M; Leblanc, JC; Renwick, AG; Setzer, W; Schlatter, J; Smith, B; Slob, W; Williams, G; Wildemann, T (2010). Application of the Margin of Exposure (MOE) approach to substances in food that are genotoxic and carcinogenic. Food Chem. Toxicol. 48(1): S2-24.

Brandli, RC; Bucheli, TD; Kupper, T; Mayer, J; Stadelmann, FX; Tarradellas, T (2007). Fate of PCBs, PAHs and their source characteristic ratios during composting and digestion of sourceseparated organic waste in full-scale plants, Environ. Pollut. (148):520-528.

Conte, F; Copat, C; Longo, S; Conti, GO; Grasso, A; Arena, G; Dimartino, A; Brundo, MV; Ferrante, M (2016). Polycyclic aromatic hydrocarbons in Haliotis tuberculata (Linnaeus, 1758) (Mollusca, Gastropoda): considerations on food safety and source investigation. Food and Chem. Toxicol. (94):57-63

Daka, ER; Moslen, M (2013). Spatial and Temporal Variation of Physico-Chemical Parameters of Sediment from Azuabie Creek of the Upper Bonny Estuary, Niger Delta. Res. J. Environ. Earth Sci. 5(4): 219-228 
Ding, C; Ni, H; Zeng, H (2012). Parent and halogenated polycyclic aromatic hydrocarbons in rice and implications for human health in China. Environ. Pollut. (168) :80-86, https://doi.org/10.1016/j.envpol.2012.04.025.

Domingo, JL; Nadal, M (2015). Human dietary exposure to polycyclic aromatic hydrocarbons: a review of the scientific literature. Food and Chem. Toxicol. (86) :144-153. doi:10.1016/J.FCT.2015.10.002

EC, (2006). European Commission regulation, Setting maximum levels for certain contaminants in foodstuffs Off. J. Eur. Union (364): 5-24.

EFSA, (2008). European Food Safety Authority (2008) Scientific opinion of the panel on contaminants in the food chain on a request from the European Commission on polycyclic aromatic hydrocarbons in food, EFSA J. (724) :1-114.

European Food Safety Authority (2005). Opinion of the Scientific Committee on a Request from EFSA Related to a Harmonised Approach for Risk Assessment of Substances Which Are Both Genotoxic and Carcinogenic (Request No EFSAQ-2004- 020). Adopted on 18 October, Available at: (2005) http://www.efsa.eu. int/science/sc_commitee/ sc_opinions/ 1201_en.html.

European Food Safety Authority (EFSA)(2005). Opinion of the Scientific Committee on a Request From EFSA Related to a Harmonised Approach for Risk Assessment of Substances Which Are Both Genotoxic and Carcinogenic (Request No EFSA-Q-2004- 020). Adopted on 18 October, Available at: (2005) http://www.efsa.eu.int/science/ commitee/sc_opinions/1201_en.html.

FAO, (2014). Food Agriculture Organization Fishery and aquaculture statistics 2014, Statistics and Information Service of the Fisheries and Aquaculture Department/Service. 2014, FAO, Rome, Roma, 2014http://www.fao.org/3/ai5716t.pdf.

FAO/WHO, (2005). Joint FAO/WHO Expert Committee on food additives, Sixty-fourth meeting, Rome, 8-17 February, Available at: Summary and conclusions, 2005, http://www.who.int/ipcs/food/jecfa/ summaries/summary_report_64_final.pdf.
Food Safety Authority of Ireland (FSAI) (2015). Polycyclic Aromatic Hydrocarbons (PAHs) in Food. Toxicology Factsheet Series Issue No. (2):1-10

Halek, F; Nabi, G; Kavousi, A (2007). Polycyclic aromatic hydrocarbons study and toxic equivalency factor (TEFs) in Tehran, Iran. Environ. Monit. Assess. (143) :303-311, https://doi.org/10.1007/s10661-007-9983-9989.

Honda, M; Qiu, X; Koyama, J; Uno, S; Undap, SL; Shimasaki, Y; Oshima, Y (2018). The wharf roach, Ligia sp., A novel indicator of polycyclic aromatic hydrocarbon contamination in coastal areas. Int. J. Environ. Res. (12): 1-11.

Huang, T; Guo, Q; Tian, H; Mao, X; Ding, Z; Zhang, G; Li, J; Ma, J; Gao, H (2014). Assessing spatial distribution, sources, and human health risk of organochlorine pesticide residues in the soils of arid and semiarid areas of northwest China. Environ, Sci, Pollut. Res. 21:6124-6135, https://doi.org/10.1007/s11356-014-2505-8.

Inengite AK, Oforka NC, Osuji LC (2010) Evaluation of polycyclic aromatic hydrocarbon in sediments of Kolo Creek in the Niger Delta, Int. J. Appl. Environ. Sc. 5(1):127-143.

Jing, N; Shi, J; Duan, X; Wang, B; Huang, N; Zhao, X (2013). Health risk assessment of dietary exposure to polycyclic aromatic hydrocarbons in Taiyuan, China, J. Environ. Sci. China. (26):432439.

Moslen, M; Ekweozor, IKE (2016). Variation in Abundance and Diversity of Macrobenthic fauna of Ekerekana and Okochiri Creeks in the upper Bonny Estuary, Nigeria. Curr. Stud. Comp. Edu. Sci. Technol. (3):158-168

Moslen, M; Ekweozor, IKE; Minimah, I; Ebere, N (2017). Variation of Persistent Organic Pollutants (Pops) in surface water, sediment and fish from a tidal creek in the Niger Delta, Nigeria. Nig. J. Oil Gas Technol. 3(1): 229-239

Moslen, M; Miebaka, CA; Boisa, N (2019). Bioaccumulation of Polycyclic Aromatic Hydrocarbon (PAH) in a bivalve (Arca senilisblood cockles) and health risk assessment. Toxicol. Rept. (6): 990-997

Nakata, H; Uehara, K; Goto, Y; Fukumura, M; Shimasaki, H; Takikawa, K; Miyawaki, T (2014). 
Polycyclic aromatic hydrocarbons in oysters and sediments from the Yatsushiro Sea, Japan: Comparison of potential risks among PAHs, dioxins and dioxin-like compounds in benthic organisms. Ecotoxicol. Environ. Saf. (99): 61-68

Nasher, E; Heng, LY; Zakaria, Z; Surif, S (2013). Assessing the ecological risk of polycyclic aromatic hydrocarbons in sediments at Langkawi Island, Malaysia. Sci. World J. 1-3.

Nisbet I, LaGoy P (1992) Toxic equivalency factors (TEFs) for polycyclic aromatic hydrocarbons (PAHs), Regul. Toxicol. Pharmacol. (16): 290300

Nwaichi, EO; Ntorgbo, SA (2016). Assessment of PAHs levels in some fish and seafood from different coastal waters in the Niger Delta, Toxicol. Rep. (3): 167-172

Nyarko, E; Botwe, BO; Klubi, E (2011). Polycyclic aromatic hydrocarbons (PAHs) levels in two commercially important fish species from the Coastal Waters of Ghana and their carcinogenic health risks, West Afr. J. Appl. Ecol. (19):53-66.

Olayinka, OO; Adewusi, AA; Olujimi, OO; Aladesida, AA (2019). Polycyclic Aromatic Hydrocarbons in Sediment and Health Risk of Fish, Crab and Shrimp around Atlas Cove, Nigeria J Health Pollut 9(24): 1-20

Pena, T; Pensado, L; Casais, C; Mejuto, C; Phan-TanLuu, R; Cela, R (2006). Optimization of a microwave-assisted extraction method for the analysis of polycyclic aromatic hydrocarbons from fish samples, J. Hromatogr. (A1121):163169.

Pham, LT; Hoang, TTT; Tu, LCT; Tran, YHT; Le, BD; Nguyen, DV; Do, HX; Thai, NV (2019). Bioaccumulation and health risk assessment of polycyclic aromatic hydrocarbons in oyster (Crassostrea sp.) and gastropod (Cymatium sp.) species from the Can Gio Coastal Wetland in Vietnam. Mar. and Freshwater Res. https://doi.org/10.1071/MF19055

Qu, C; Qi, S; Yang, D; Huang, H; Zhang, J; Chen, W; Yohannes, H; Sandy, E; Yang, J; Xing, X (2015). Risk assessment and influence factors of organochlorine pesticides (OCPs) in agricultural soils of the hill region: a case study from Ningde, southeast China, J. Geochem. Explor. (149):4351 ,
Safahieh, A; Mahmoodi, M; Nikpoor, Y; Ghanemi, K (2011). PAHs Concentration in Ark clam (Barbatia helblingii) from South Persian Gulf, Bushehr. Iran Inter. J. Environ. Sci. and Dev. 2(5)

Szewczynska, M; Posniak, M; Dobrzynska, E (2013). Study on individual PAHs content in ultrafine particles from solid fractions of diesel and biodiesel exhaust fumes, J. Chem. Article ID 528471, 10pp.

Tongo, I; Etor, IEE; Ezemonye, LIN (2018). Human health risk assessment of PAHs in fish and shellfish from Amariaria community, Bonny River, Nigeria, J. Appl. Sci. Environ. Manage. 22 (5):731-736

Tongo, I; Ogbeide, O; Ezemonye, L (2017). Human health risk assessment of polycyclic aromatic hydrocarbons (PAHs) in smoked fish species from markets in Southern Nigeria, Toxicol. Rept. (4): 55-61

Tongo, I; Ogbeide, O; Ezemonye, LIN (2015). PAH levels in smoked fish species from selected markets in Benin city, Nigeria: potential risks to human health, Proceedings of the 7th International Toxicology Symposium in Africa Held on the 31st of August, 2015.

US Environmental Protection Agency (1993), Provisional Guidance for Quantitative Risk Assessment of Polycyclic Aromatic Hydrocarbons. EPA/600/R-93/089, U.S. Environmental Protection Agency. Washington, DC: Office of Research and Development, 1993, pp. 1993

US Environmental Protection Agency (2001), Integrated Risk Information System: Benzo[a]pyrene (BaP) (CASRN 50-32-8), Available from: U.S. Environmental Protection Agency, 2001 , http://www.epa.gov/iris/subst/0136.htm.

Wenz, T; Simon, R; Anklam, E; Kleiner, J (2006). Analytical methods for polycyclic aromatic hydrocarbons (PAHs) in food and the environment needed for new food legislation in the European Union. Trends Analyt. Chem. (25):716-725.

WHO/IPCS (2009). Environmental Health Criteria 239: Principles for modelling dose-response for the risk assessment of chemicals. World Health 
Organization, Geneva. Available at: http://whqlibdoc.who.int/publications/ 2009/9789241572392_eng.pdf.

Wickliffe, JK; Simon-Friedt, B; Howard, JL; Frahm, E; Meyer, B; Wilson, MJ; Pangeni, D; Overton, EB (2018). Consumption of Fish and Shrimp from Southeast Louisiana Poses No Unacceptable Lifetime Cancer Risks Attributable to HighPriority Polycyclic Aromatic Hydrocarbons. Risk. Ana. 38(9): 1944 -1961

WRMS (2010). Thais coronata (Lamarck, 1816). Retrieved through: World Register of Marine Species on 24 April 2010.
Wu, M; Xia, Z; Zhang, Q; Yin, J; Zhou, Y; Yang, H (2016). Distribution and health risk assessment on dietary exposure of polycyclic aromatic hydrocarbons in vegetables in Nanjing, China. J. Chem. 1581253,

Xia, Z; Duan, X; Qiu, W; Liu, D; Wang, B; Tao, S; Jiang, Q; Lu, B; Song, Y; Hu, X (2010). Health risk assessment on dietary exposure to polycyclic aromatic hydrocarbons (PAHs) in Taiyuan, China. Sci. Total Environ. (408):5331-5337 